\title{
Toll-like receptor-9 is involved in the development of $B$ cell stimulating factor-induced systemic lupus erythematosus
}

\author{
YING LIU $^{1-3}$, FENG ZHAN $^{3}$, XIAO ZHANG ${ }^{1,2}$ and SHUDIAN LIN ${ }^{3}$ \\ ${ }^{1}$ Graduate School of Southern Medical University, Guangzhou, Guangdong 510515; ${ }^{2}$ Department of \\ Rheumatology and Clinical Immunology, Guangdong General Hospital and Guangdong Academy of Medical Sciences, \\ Guangzhou, Guangdong 510080; ${ }^{3}$ Department of Rheumatology and Clinical Immunology, \\ Hainan General Hospital, Haikou, Hainan 570000, P.R. China
}

Received January 3, 2017; Accepted August 25, 2017

DOI: $10.3892 / \mathrm{etm} .2017 .5411$

\begin{abstract}
The objective of the present study was to investigate the role of Toll-like receptor (TLR)-9 in B lymphocyte stimulating factor (BLyS)-induced systemic lupus erythematosus (SLE) in mice. The anti-double stranded (ds)DNA antibody titer, levels of complement proteins (C3 and C4), interleukin (IL)-10 and the disease activity [assessed by the erythrocyte sedimentation rate (ESR) and C-reactive protein (CRP) level] were measured. A total of 21 transgenic female mice (aged 8-10 weeks and weighing 30-40 g) expressing the Epstein-Barr virus membrane antigen, BLLF1, were studied. Mice were randomly divided into the control, the BLyS inhibition and the TLR-9 inhibition groups, with 7 mice in each group. Mice in the blank control group received intraperitoneal injections of normal saline, mice in the BLyS inhibition group received intraperitoneal injections of anti-BR3 monoclonal antibody (5,000 ng/day) and mice in the TLR-9 inhibition group received intraperitoneal injections of anti-human TLR-9 antibody ( $250 \mathrm{ng} /$ day). The treatment regimens continued for 10 days, followed by the collection of peripheral venous blood. The relative levels of TLR-9 mRNA were measured by reverse transcription-quantitative polymerase chain reaction. Furthermore, the BLyS protein concentration and IL-10 levels were measured by ELISA. TLR-9 mRNA, BLyS, IL-10, anti-dsDNA antibody titer, C3, C4, ESR and CRP levels of the blank control group were significantly higher than those of the other two groups $(\mathrm{P}<0.05)$. The differences in comparison of these indexes between the BLyS inhibition and TLR-9 inhibition groups were not statistically significant
\end{abstract}

Correspondence to: Professor Xiao Zhang, Department of Rheumatology and Clinical Immunology, Guangdong General Hospital and Guangdong Academy of Medical Sciences, 106 Zhongshan 2nd Road, Guangzhou, Guangdong 510080, P.R. China

E-mail: 13922255387@163.com

Key words: toll-like receptor signal, B lymphocyte stimulating factor, systemic lupus erythematosus, signal pathway, double stranded DNA, interleukin-10
( $P>0.05)$, with the exception of TLR-9 mRNA and BLyS. In conclusion, the TLR-9 signaling pathway may be important for BLyS-induced SLE, and regulation of the inflammatory immune level.

\section{Introduction}

Systemic lupus erythematosus (SLE) is a chronic, progressive and recurrent autoimmune disease, which affects multiple systems and organs of the body, including the skin, serosa, joints, kidneys and the central nervous system (1). It is characterized by the activation, proliferation and hyperfunction of B lymphocytes, as well as humoral and cellular immunity functional disorder (2). The majority of cases of SLE are diagnosed in females of childbearing age (3). SLE is a difficult disease to diagnose as it present with multiple nonspecific early symptoms, meaning it is not possible to detect SLE using a single laboratory test (4). In the majority of cases a confirmed diagnosis of SLE is only possible following organ damage (5). Children who are affected by SLE typically present with severe diseased states requiring special management (6). Older patients with SLE may have complicating co-morbid conditions, which makes treatment difficult (7). Extensive therapeutic advances have been made, over the last decade, however, treatment regimens are often long and there have been multiple previous reports of the use of ineffective drugs that do not target the desired site $(8,9)$. There are several promising strategies that are being studied as potential novel treatments for SLE $(10,11)$.

Animal and clinical studies of SLE pathogenesis have revealed that B lymphocyte stimulating factor (BLyS) may promote the activation and proliferation of B-lymphocytes, which leads to the production of large amounts of immunoglobulins and autoantibodies $(12,13)$. Immunologic injury is caused by formation of immune complexes, complement-mediated cytolysis, opsonophagocytosis and antibody-mediated cell-dependent cytotoxicity (14). Toll-like receptors (TLRs) are a family of proteins that recognize an innate immunity pattern. They are widely expressed in various tissues and cells of the human body and are able to recognize and bind to conserved pathogen-associated molecules. This may trigger a series of signal transduction pathways that lead 
to the release of inflammatory mediators, which may then activate acquired immunity. TLRs are regarded as a bridge between innate and acquired immunity (15). Furthermore, human B lymphocytes only express TLR-9 and TLR-10 (16). A study by Medzhitov et al (17) previously reported that TLRs regulate the activation of B lymphocytes and antibody production in vivo. Based on these observations, the aim of the present study was to investigate the TLR-9 signal transduction pathway in BLyS-induced SLE in transgenic mice.

\section{Materials and methods}

SLE transgenic mice. In total, 21 transgenic female mice (aged 8-10 weeks and weighing 30-40 g) expressing the Epstein-Barr virus membrane antigen, BLLF1, were used for experiments. Mice were purchased from the Laboratory Animal Research Center, Peking University Health Science Center (Beijing, China). Mice were fed as usual for 1 week, after which experiments were performed. Mice were kept in standard air-conditioned rooms, under a $12 \mathrm{~h}$ light/dark cycle, maintained at $25^{\circ} \mathrm{C}$ in $40-60 \%$ humidity with food and water available ad libitum. The present study was approved by the Medical Ethics Committee of Hainan General Hospital (Haikou, China).

Methods. Mice were randomly divided into the blank control, BLyS inhibition and TLR-9 inhibition groups, with 7 mice in each group. The mice in the blank control group received intraperitoneal injections $(0.5 \mathrm{ml})$ of normal saline $(0.90 \%$ $\mathrm{w} / \mathrm{v} \mathrm{NaCl}$ in water), mice in the BLyS inhibition group received intraperitoneal injections of anti-BR3 monoclonal antibody (cat. no. D201-3; 5,000 ng/day for 10 days; Beijing Hanpu Medical Biology Research Institute, Beijing, China), and mice in the TLR-9 inhibition group received intraperitoneal injections (250 ng/day for 10 days) of anti-human TLR-9 antibody (1:50 dilution; cat. no. IMG-305a; Imgenex; Novus Biologicals, LLC, Littleton, CO, USA). Peripheral venous blood was collected prior to intervention and after maintaining the mice on normal feed for 10 days. The relative levels of TLR-9 mRNA were measured by reverse transcription-quantitative polymerase chain reaction (RT-qPCR). The BLyS protein concentration and IL-10 level were measured by ELISA (Invitrogen; Thermo Fisher Scientific, Inc., Waltham, MA, USA). The anti-double stranded (ds)DNA antibody titer was measured using a dot blot assay, which determines whether an antibody-based detection system would work effectively. Purified bovine serum albumin (Sigma-Aldrich; Merck KGaA, Darmstadt, Germany) and the test sample were spotted onto the membrane and the membrane was subsequently incubated with the appropriate primary $\left(25^{\circ} \mathrm{C}\right.$ for $4 \mathrm{~h}$ ) and secondary antibodies $\left(4^{\circ} \mathrm{C}\right.$ for $\left.24 \mathrm{~h}\right)$, to determine whether a signal could be detected. The antibodies used were obtained from the following kits: The complement $\mathrm{C} 3$ and $\mathrm{C} 4$ levels were estimated using Abcam Complement ELISA kits (cat. nos. ab157711 and ab108824; Abcam, Cambridge, UK). The erythrocyte sedimentation rates (ESRs) were measured using an ESR kit (cat. no. 21200213; Thermo Fisher Scientific, Inc.) and C-reactive protein (CRP) levels were measured using an ELISA kit (cat. no. RAB0096; Sigma-Aldrich; Merck KGaA).
$R T-q P C R$. The blood was centrifuged at $1,006.2 \mathrm{x} \mathrm{g}$ for $20 \mathrm{~min}$ at $4^{\circ} \mathrm{C}$ (Beijing Liuyi Instrument Factory, Beijing, China), the serum was isolated and an equal volume of lymphocyte separation solution (Shanghai Yanjin Biology \& Science Co., Ltd., Shanghai, China) was added to isolate the mononuclear cells. Total RNA was extracted with TRIzol (Sigma-Aldrich; Merck $\mathrm{KGaA}$ ). $1.1 \%$ agarose gel electrophoresis and visualized using ethidium bromide (Thermo Fisher Scientific, Inc.) and an ultraviolet spectrophotometer (Thermo Fisher Scientific, Inc.) were used to measure the quality and concentration of the total RNA, respectively. Furthermore, RNA was treated with RNAase A (Sigma-Aldrich; Merck KGaA) and stored at $-80^{\circ} \mathrm{C}$. Following this, cDNA was synthesized according to the manufacturer's protocol of the reverse transcription kit (Fermentas; Thermo Fisher Scientific, Inc.). Primers were designed by Shanghai Shengong Biology Co.,Ltd.,(Shanghai,China). The PCR machine used was from Shanghai Sanke Instrument Co., Ltd. (Shanghai, China). The primer sequences were as follows: TLR-9 forward, 5'-TGGATACGTTTCCTTATAAG-3' and reverse, 5'-GAAATG GAGGCACCCCTTC-3' (418 bp); and $\beta$-actin (internal control) forward, 5'-ATCATGTTTGAGACCTTCAACA-3' and reverse, 5'-CATCTCTTGCTCGAAGTCCA-3' (300 bp). For qPCR, the reaction system included $2 \mu \mathrm{l}$ cDNA template, $0.5 \mu \mathrm{l}$ of each primer, $9 \mu 1$ 2.5X Real Master mix, $9 \mu 1$ 20X SYBR solution (Thermo Fisher Scientific, Inc.) and water to a total volume of $20 \mu \mathrm{l}$. The thermal profile was as follows: Pre-degeneration at $95^{\circ} \mathrm{C}$ for $2 \mathrm{~min}$, degeneration at $95^{\circ} \mathrm{C}$ for $45 \mathrm{sec}, 60^{\circ} \mathrm{C}$ for $20 \mathrm{sec}$ and $75^{\circ} \mathrm{C}$ for $60 \mathrm{sec}$ for a total of 30 cycles, and with an extension at $72^{\circ} \mathrm{C}$ for $5 \mathrm{~min}$. Each sample was detected three times, and the mean values were obtained as the target gene expression as determined by the relative quantification method $\left(2^{-\Delta \Delta \mathrm{Cq}}\right)(18)$. Following the reaction, the specificity of primers was analyzed using melting curves, and $1.1 \%$ agarose gel electrophoresis was performed to identify the PCR amplification products.

Other indexes. ELISA (cat. no. A20180) and an Immunogold Labeling kit were purchased from Invitrogen (Thermo Fisher Scientific, Inc.) and used according to the manufacturer's protocols. The automatic biochemical analyzer, AU5800, was purchased from Beckman Coulter, Inc. (Brea, CA, USA).

Statistical analysis. SPSS 20.0 software (IBM Corp., Armonk, NY, USA) was used for statistical analysis. The measurement data were presented as the mean \pm standard deviation. Comparisons between groups were performed by one-way analysis of variance followed by Fisher's least significant difference method. Comparisons within groups were performed using the paired t-test. $\mathrm{P}<0.05$ was considered to indicate a statistically significant difference.

\section{Results}

Comparison of the relative expression of TLR-9 $m R N A$. The differences in the levels of TLR-9 mRNA between the three groups prior to intervention were not statistically significant. There was no significant alteration to the TLR-9 level in the control group following intervention. However, the levels of TLR-9 mRNA in the BLyS and TLR-9 inhibition groups significantly decreased following intervention compared with their levels prior to intervention $(\mathrm{P}<0.05)$, the levels of TLR-9 
Table I. Relative mRNA expression of TLR-9 mRNA in the different groups.

TLR-9 mRNA expression level

\begin{tabular}{|c|c|c|c|c|}
\hline \multirow[b]{2}{*}{ Group } & & \multirow[b]{2}{*}{ t-value } & \multirow[b]{2}{*}{ P-value } \\
\hline & Before intervention & After intervention & & \\
\hline Control & $0.4547 \pm 0.0219$ & $0.4562 \pm 0.0315$ & -0.089 & 0.932 \\
\hline BLyS inhibitor & $0.4627 \pm 0.0311$ & $0.2581 \pm 0.0270$ & 12.845 & $<0.01$ \\
\hline TLR-9 inhibitor & $0.4630 \pm 0.0248$ & $0.1513 \pm 0.0311$ & 22.792 & $<0.01$ \\
\hline F-value & 0.226 & 187.009 & - & - \\
\hline P-value & 0.800 & $<0.01$ & - & - \\
\hline
\end{tabular}

BLyS, B lymphocyte stimulating factor; TLR-9, Toll-like receptor-9.

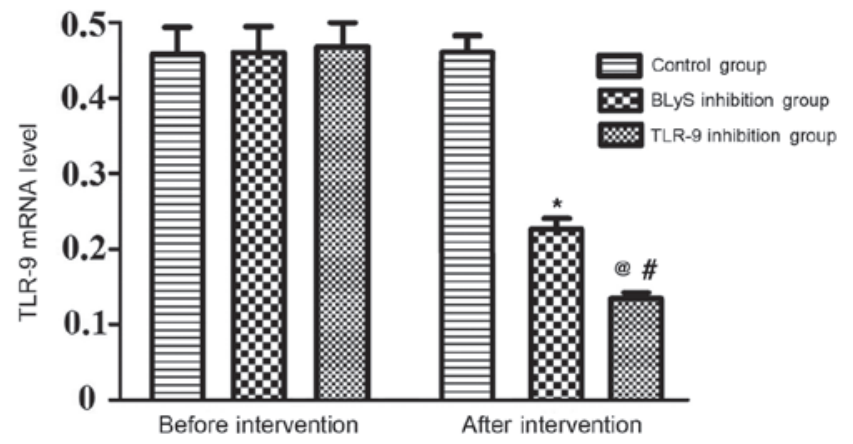

Figure 1. Comparison of the relative expression of TLR-9 mRNA. " $\mathrm{P}<0.05$ vs. the BLyS inhibition group prior to intervention; ${ }^{\#} \mathrm{P}<0.05$ vs. the TLR- 9 inhibition group prior to intervention; ${ }^{\circledR} \mathrm{P}<0.05$ vs. the BLyS inhibition group after intervention. BLyS, B lymphocyte stimulating factor; TLR-9, Toll-like receptor-9.

mRNA in the TLR-9 inhibition group were significantly lower than those in the BLyS inhibition group following intervention $(\mathrm{P}<0.05)$ (Table I and Fig. 1).

Comparison of the levels of BLyS and IL-10. The differences in the levels of BLyS and IL-10 in the three groups prior to intervention were not statistically significant $(\mathrm{P}>0.05)$. Additionally, there was no significant change in the levels in the control group following intervention. The BLyS protein concentration and IL-10 level of the BLyS and TLR-9 inhibition groups significantly decreased following intervention compared with the levels before intervention $(\mathrm{P}<0.05)$. The differences between the BLyS and TLR-9 inhibition groups were not statistically significant prior to intervention (Table II and Fig. 2). However, following intervention there was a significant difference between the IL-10 expression in the BLyS and TLR-9 inhibition groups $(\mathrm{P}<0.05)$.

Comparison of anti-dsDNA, C3, C4, ESR and CRP levels. The differences in the levels of anti-dsDNA antibody, C3, C4, ESR and CRP levels of the three groups prior to intervention were not statistically significant. Furthermore, there were no significant alterations to these levels observed in the control group following intervention. The above indexes in the BLyS and TLR-9 inhibition groups decreased significantly following intervention compared with the levels before intervention $(\mathrm{P}<0.05)$. Furthermore, the differences in the levels of the above indexes between the BLyS and TLR-9 inhibition groups following intervention were not statistically significant (Table III and Fig. 3).

\section{Discussion}

Mice with congenital deficiency of BLyS exhibit a reduced number of B lymphocytes and decreased levels of immunoglobulin (19). By contrast, B lymphocytes in transgenic mice with overexpression of BLyS increase in number and may lead to hyperimmunoglobulinemia (20). In patients with SLE, various high-titer autoantibodies, such as anti-dsDNA, have been detected in circulation, and the level of immune complexes has been demonstrated to increase, as well as the immunoglobulin deposited in the kidney (21). BLyS antagonists may be used to inhibit progression and improve the survival rate of SLE (22). In the present study, it was revealed that the levels of BLyS in the plasma or serum of patients with SLE were significantly higher than those of the control subjects. Additionally, the biological activity of BLyS in circulation was significantly higher compared with the control group, and was closely associated with anti-dsDNA antibody titer, disease activity, ESR, CRP levels, and serum immunoglobulin G (23). A previous study indicated that BLyS may block the expression of apoptosis-related genes in B lymphocytes downstream of signals from the B cell receptor (BCR) (24). Furthermore, TLR signaling was demonstrated to serve an indispensable role in BLyS transgenic mice by upregulating the expression of anti-apoptotic genes, including cluster of differentiation (CD)40 (25).

A total of 13 members of the TLR family have been identified (26). Lipopolysaccharide (LPS) from the wall of Gram-negative bacteria is the main ligand of TLR-9 (27). Additionally, TLR-9, CD14, myeloid differentiation protein 2 and LPS binding protein combine to form the LPS recognition receptor complex, with a high affinity and signal transduction function (28). The LPS recognition receptor may cause the translocation of nuclear factor $-\kappa \mathrm{B}(\mathrm{NF}-\kappa \mathrm{B})$ from the cytoplasm to the nucleus by myeloid differentiation protein 88 (MyD88)-dependent or independent signaling pathways and bind with the NF-site in the promoter region of inflammatory response regulator genes, promoting the initiation of transcription and translation of genes encoding inflammatory cytokines, as well as the large release of cytokines (29). The immune response of the organism is thereby initiated (30). 
Table II. Protein expression of BLyS and IL-10 in the different groups.

\begin{tabular}{|c|c|c|c|c|c|c|c|c|}
\hline \multirow[b]{2}{*}{ Group } & \multicolumn{4}{|c|}{$\mathrm{BLyS}, \mu \mathrm{g} / 1$} & \multicolumn{4}{|c|}{ IL-10, pg/ml } \\
\hline & $\begin{array}{c}\text { Before } \\
\text { intervention }\end{array}$ & $\begin{array}{c}\text { After } \\
\text { intervention }\end{array}$ & t-value & P-value & $\begin{array}{c}\text { Before } \\
\text { intervention }\end{array}$ & $\begin{array}{c}\text { After } \\
\text { intervention }\end{array}$ & t-value & P-value \\
\hline Control & $49.6 \pm 3.4$ & $47.4 \pm 2.8$ & 1.630 & 0.154 & $273.1 \pm 24.7$ & $292.8 \pm 32.1$ & -1.342 & 0.228 \\
\hline BLyS inhibitor & $52.1 \pm 3.7$ & $13.1 \pm 1.6$ & 21.726 & $<0.01$ & $290.3 \pm 35.3$ & $171.8 \pm 16.5$ & 8.355 & $<0.01$ \\
\hline TLR-9 inhibitor & $53.2 \pm 1.9$ & $26.5 \pm 1.6$ & 33.203 & $<0.01$ & $275.0 \pm 31.3$ & $182.3 \pm 38.7$ & 4.983 & 0.002 \\
\hline F-value & 2.451 & 493.896 & - & - & 0.661 & 33.730 & - & - \\
\hline P-value & 0.114 & $<0.01$ & - & - & 0.528 & $<0.01$ & - & - \\
\hline
\end{tabular}

BLyS, B lymphocyte stimulating factor; TLR-9, Toll-like receptor-9; IL-10, interleukin-10.

A

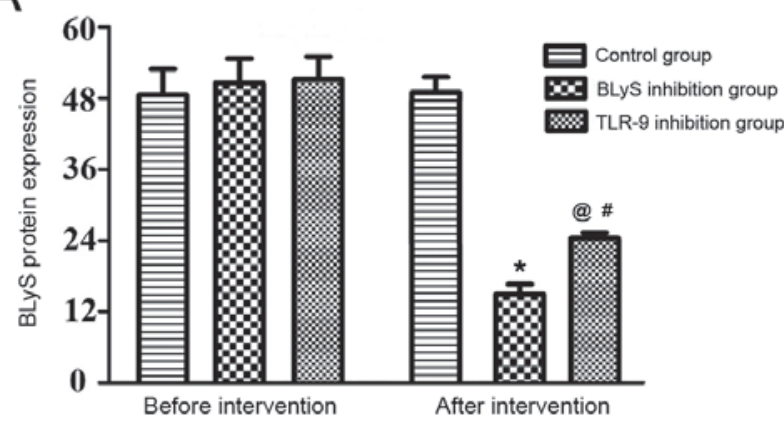

B

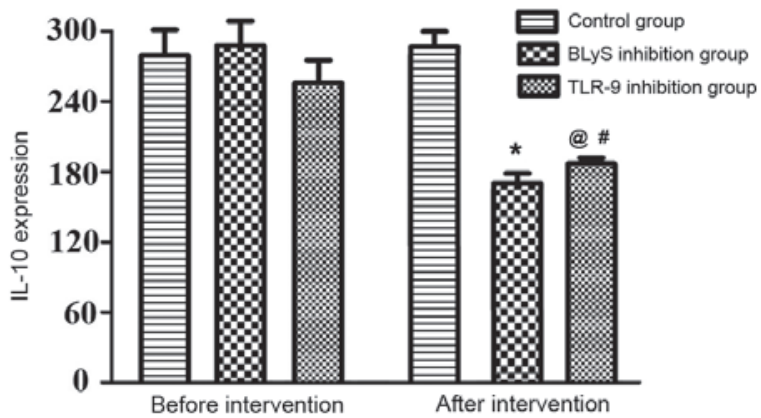

Figure 2. Comparison of the relative levels of (A) BLyS and (B) IL-10. ${ }^{*} \mathrm{P}<0.05$ vs. the BLyS inhibition group prior to intervention; ${ }^{\#} \mathrm{P}<0.05$ vs. the TLR-9 inhibition group prior to intervention; ${ }^{\circledR} \mathrm{P}<0.05$ vs. the BLyS inhibition group after intervention. BLyS, B lymphocyte stimulating factor; TLR-9, Toll-like receptor-9; IL, interleukin.

A
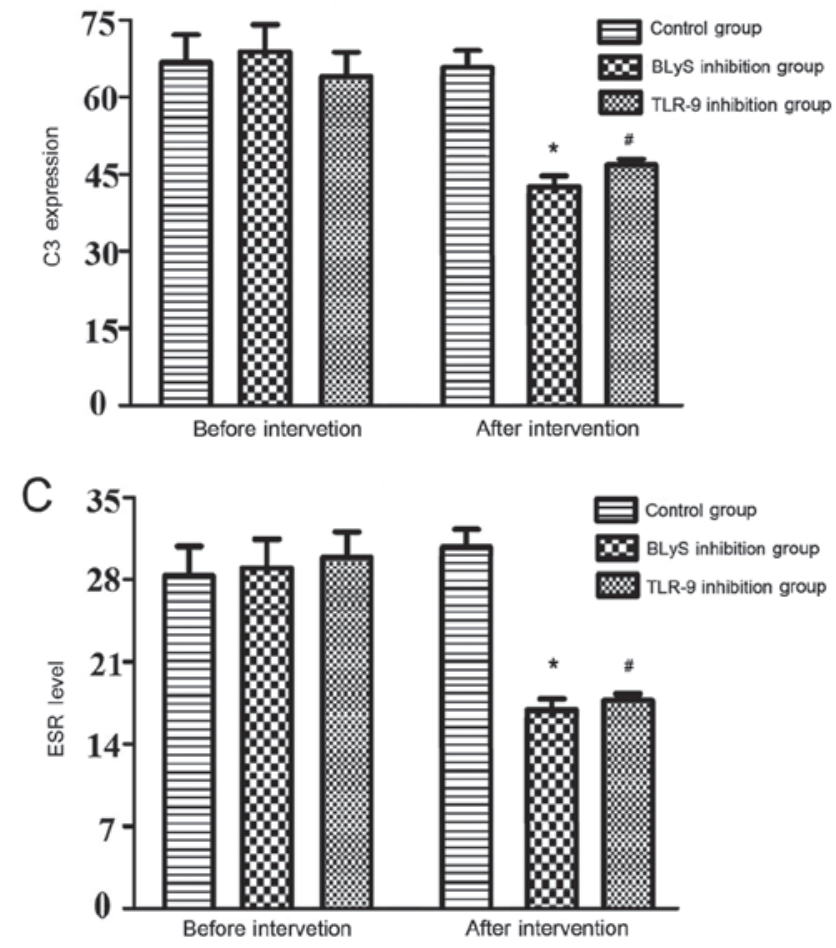

B

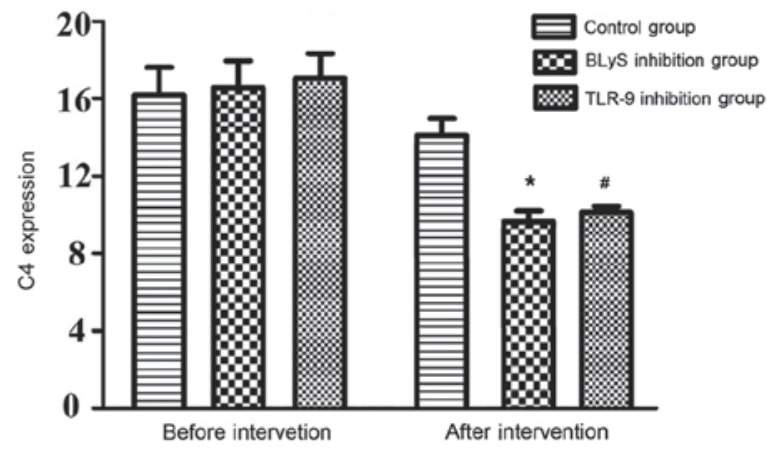

D

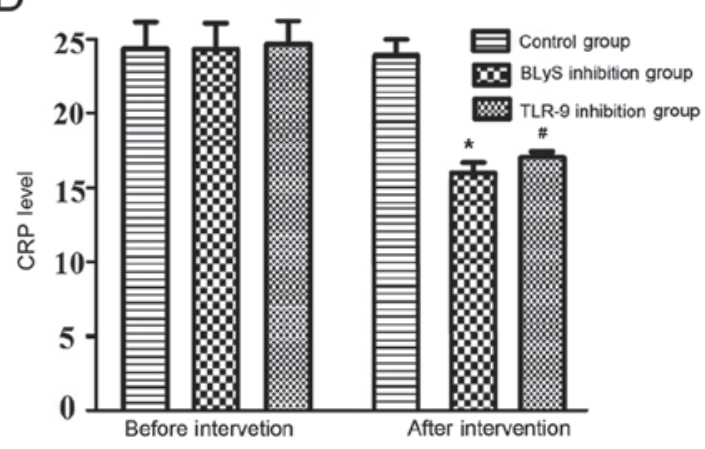

Figure 3. Comparison of anti-dsDNA, (A) C3, (B) C4, (C) ESR and (D) CRP relative levels in the different groups. * $<<0.05$ vs. the BLyS inhibition group prior to intervention; ${ }^{\text {P }}<0.05$ vs. the TLR-9 inhibition group prior to intervention. BLyS, B lymphocyte stimulating factor; TLR-9, Toll-like receptor-9; ESR, erythrocyte sedimentation rate; CRP, C-reactive protein; C3, complement 3; C4, complement 4. 
When BCR and CD40 are combined or triggered by $\mathrm{CpG}$ DNA, TLR expression increases (31). Furthermore, the induced expression of TLRs on B lymphocytes may serve a role in the pathological process of autoimmune diseases (32). A study by Marshak-Rothstein et al (33) reported that B lymphocytes that express membrane-bound immunoglobulin $\mathrm{M}$ rheumatoid factor may be activated by chromosome-chromosome antibody immune complexes through the TLR9-MyD88 dependent pathway. The chromosome-chromosome antibody immune complex may then be endocytosed into the endoplasmic reticulum through BCR-mediated mechanisms, which then transmit signals by TLR9 that is expressed in the endoplast. Therefore, TLRs on B lymphocytes connect innate immunity with autoimmunity (34).

The differentiation and activation of helper $\mathrm{T}$ cells is not sufficient for $\mathrm{T}$ cell-dependent activation of B lymphocytes. In addition to the assistance of $\mathrm{CD}^{+} \mathrm{T}$ cells, antigen-specific $\mathrm{T}$ cell-dependent antibody responses require the activation of TLRs on B lymphocytes (35). The function of TLRs on B lymphocytes may assist BCR to identify antigens of microbial origin, and assist with the anti-infection response (36).

Cytokines serve a critical role in regulating disease activity and organ injury in SLE. Of these cytokines, IL-10 is predominantly produced by mononuclear macrophages, fibroblasts and endothelial cells and functions to stimulate the maturation of B-lymphocytes and the secretion of immunoglobulins (37). A study in New Zealand Black and New Zealand White mice revealed that IL-10 directly caused the pathogenesis of SLE (38), indicating that the rise of exogenous IL-10 in vitro may lead to increased levels of immunoglobulin $G$ and anti-dsDNA antibodies that are produced by B lymphocytes of old $\mathrm{B} / \mathrm{W}$ mice, and may reduce albuminuria as well as the fatality rate. A previous study reported that IL-10 is highly and spontaneously expressed in the peripheral blood of patients with lupus, and is associated with disease activity (39). Lymphocytes isolated from patients with SLE may spontaneously increase IL-10 production in vitro, and anti-IL-10 may reduce the anti-ds-DNA level (40). Furthermore, multiple models of lupus have demonstrated the positive therapeutic effects of IL-10 and IL-10 receptor antagonists (41). In addition to inhibiting the ultimate IL-10 output, inhibition of the source of IL-10 production is an attractive concept.

At present, there are three types of murine model of SLE: Spontaneous, artificial induction and gene regulation types (42). The spontaneous type has a specific genetic background and good genetic stability, which is of great significance in the studies of genetic factors that affect SLE (43). The artificial induction type is suitable for short-term studies, and the majority of the mice succumb to the disease $\sim 5$ months after induction of SLE. Mice of the gene regulation type, including transgenic and knockout mice, may be used to perform genetic level analyses for studies on the mechanism of SLE (44).

In the present study, it was concluded that TLR-9 mRNA, BLyS, IL-10, anti-dsDNA antibody titer, C3, C4, ESR and CRP levels of the blank control group were significantly higher than those of the other two groups. These results are consistent with the findings of previous studies (45-48). Additionally, the difference in comparison of the above indexes between the BLyS and the TLR-9 inhibition groups were not statistically significant, with the exception of TLR-9 mRNA and BLyS. 
This implied that TLR-9 represents an important signaling pathway that may regulate the inflammatory immune level for BLyS-induced SLE. Therefore, inhibiting TLR-9 or BLyS expression may inhibit the process of autoimmune injury in SLE.

\section{References}

1. Thong B and Olsen NJ: Systemic lupus erythematosus diagnosis and management. Rheumatology (Oxford) 56 (suppl_1): i3-i13, 2017.

2. Golder V and Hoi A: Systemic lupus erythematosus: An update. Med J Aust 206: 215-220, 2017.

3. Murphy G and Isenberg D: Effect of gender on clinical presentation in systemic lupus erythematosus. Rheumatology (Oxford) 52: 2108-2115, 2013.

4. Sebastiani GD, Prevete I, Iuliano A and Minisola G: The importance of an early diagnosis in systemic lupus erythematosus. Isr Med Assoc J 18: 212-215, 2016.

5. Lu A, Li H, Niu J, Wu S, Xue G, Yao X, Guo Q, Wan N, Abliz P, Yang $\mathrm{G}$, et al: Hyperactivation of the NLRP3 inflammasome in myeloid cells leads to severe organ damage in experimental lupus. J Immunol 198: 1119-1129, 2017.

6. Zahran AM, Elsayh KI, Saad K, Eloseily EM, Osman NS, Alblihed MA, Badr G and Mahmoud MH: Effects of royal jelly supplementation on regulatory $\mathrm{T}$ cells in children with SLE. Food Nutr Res 60: 32963, 2016.

7. Ambrose N, Morgan TA, Galloway J, Ionnoau Y, Beresford MW and Isenberg DA; UK JSLE Study Group: Differences in disease phenotype and severity in SLE across age groups. Lupus 25: $1542-1550,2016$

8. Narang T, Sharma M, Gulati N and Kaur A: Extensive hypertrophic lupus erythematosus: Atypical presentatio. Indian J Dermatol 57: 504, 2012

9. Tunnicliffe DJ, Singh-Grewal D, Kim S, Craig JC and Tong A: Diagnosis, monitoring, and treatment of systemic lupus erythematosus: A systematic review of clinical practice guidelines. Arthritis Care Res (Hoboken) 67: 1440-1452, 2015.

10. Kaul A, Gordon C, Crow MK, Touma Z, Urowitz MB, van Vollenhoven R, Ruiz-Irastorza G and Hughes G: Systemic lupus erythematosus. Nat Rev Dis Primers 2: 16039, 2016.

11. Aringer M and Voll RE: Lupus erythematosus-Update 2016. Dtsch Med Wochenschr 141: 1785-1788, 2016 (In German).

12. Lin WY, Gong Q, Seshasayee D, Lin Z, Ou Q, Ye S, Suto E, Shu J, Lee WP, Lee CW, et al: Anti-BR3 antibodies: A new class of B-cell immunotherapy combining cellular depletion and survival blockade. Blood 110: 3959-3967, 2007.

13. Furie R, Petri M, Zamani O, Cervera R, Wallace DJ, Tegzová D, Sanchez-Guerrero J, Schwarting A, Merrill JT, Chatham WW, et al: A phase III, randonlized, placebo-controlled study of belimumab, a monoclonal antibody that inhibits B lymphocyte stimulator, in patients with systemic lupus erythematosus. Arthritis Rheum 63: 3918-3930, 2011.

14. Ko GJ, Zakaria A, Womer KL and Rabb H: Immunologic research in kidney ischemia/reperfusion injury at johns hopkins university. Immunol Res 47: 78-85, 2010.

15. Guo Y, Chai Q, Zhao Y, Li P, Qiao J and Huang J: Increased activation of toll-like receptors-7 and -8 of peripheral blood mononuclear cells and upregulated serum cytokines in patients with pediatric systemic lupus erythematosus. Int J Clin Exp Med 8: 20472-20480, 2015.

16. Khoryati L, Augusto JF, Shipley E, Contin-Bordes C, Douchet I, Mitrovic S, Truchetet ME, Lazaro E, Duffau P, Couzi L, Jacquemin C, et al: IgE inhibits Toll-like receptor 7- and Toll-like receptor 9 mediated expression of interferon- $\alpha$ by plasmacytoid dendritic cells in systemic lupus patients. Arthritis Rheumatol 68: 2221-2231, 2016

17. Medzhitov R, Kashgarian M, Shlomchik MJ, Teichmann LL and Schenten D: Signals via the adaptor MyD88 in B cells and DCs make distinct and synergistic contributions to immune activation and tissue damage in lupus. Immunity 38: 528-540, 2013

18. Livak KJ and Schmittgen TD: Analysis of relative gene expression data using real-time quantitative PCR and the 2(-Delta Delta C(T)) method. Methods 25: 402-408, 2001.

19. Cancro MP, D'Cruz DP and Khamashta MA: The role of B lymphocyte stimulator (BLyS) in systemic lupus erythematosus. J Clin Invest 119: 1066-1073, 2009.
20. Ramanujam M and Davidson A: BAFF blockade for systemic lupus erythematosus: Will the promise be fulfilled? Immunol Rev 223: 156-174, 2008 .

21. Ritterhouse LL, Crown SR, Niewold TB, Merrill JT, Roberts VC, Dedeke AB, Neas BR, Thompson LF, Guthridge JM and James JA: B lymphocyte stimulator levels in systemic lupus erythematosus: Higher circulating levels in African American patients and increased production after influenza vaccination in patients with low baseline levels. Arthritis Rheum 63: 3931-3941, 2011

22. Stohl W: Biologic differences between various inhibitors of the BLyS/BAFF pathway: Should we expect differences between belimumab and other inhibitors in development? Curr Rheumatol Rep 14: 303-309, 2012.

23. Ju S, Zhang D, Wang Y, Ni H, Kong X and Zhong R: Correlation of the expression levels of BLyS and its receptors mRNA in patients with systemic lupus erythematosus. Clin Biochem 39: 1131-1137, 2006.

24. Scholz JL, Oropallo MA, Sindhava V, Goenka R and Cancro MP: The role of B lymphocyte stimulator in B cell biology: Implications for the treatment of lupus. Lupus 22: 350-360, 2013.

25. Treml LS, Carlesso G, Hoek KL, Stadanlick JE, Kambayashi T, Bram RJ, Cancro MP and Khan WN: TLR stimulation modifies BLyS receptor expression in follicular and marginal zone B cells. J Immunol 178: 7531-7539, 2007.

26. Cargill EJ and Womack JE: Detection of polymorphisms in bovine toll-like receptors 3, 7, 8 and 9. Genomics 89: 745-755, 2007.

27. Park BS and Lee JO: Recognition of lipopolysaccharide pattern by TLR4 complexes. Exp Mol Med 45: e66, 2013.

28. Castellano G, Stasi A, Intini A, Gigante M, Di Palma AM, Divella C, Netti GS, Prattichizzo C, Pontrelli P, Crovace A, et al: Endothelial dysfunction and renal fibrosis in endotoxemia-induced oliguric kidney injury: Possible role of LPS-binding protein. Crit Care 18: 520, 2014

29. Kim BM, Jeong CB, Rhee JS and Lee JS: Transcriptional profiles

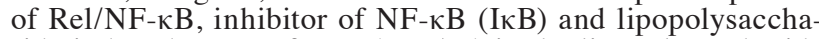
ride-induced TNF- $\alpha$ factor (LITAF) in the lipopolysaccharide (LPS) and two Vibrio sp.-exposed intertidal copepod, Tigriopus japonicus. Dev Comp Immunol 42: 229-239, 2014.

30. Thompson JS, Bixler SA, Qian F, Vora K, Scott ML, Cachero TG, Hession C, Schneider P, Sizing ID, Mullen C, et al: BAFF-R, a newly identified TNF receptor that specifically interacts with BAFF. Science 293: 2108-2111, 2001.

31. Pone EJ, Lou Z, Lam T, Greenberg ML, Wang R, Xu Z and Casali P: B cell TLR1/2, TLR4, TLR7 and TLR9 interact in induction of class switch DNA recombination: Modulation by BCR and CD40 and relevance to T-independent antibody responses. Autoimmunity 48: 1-12, 2015.

32. Liu K and Mohan C: Altered B-cell signaling in lupus. Autoimmun Rev 8: 214-218, 2009.

33. Marshak-Rothstein A, Viglianti GA, Moody KL, Uccellini MB and Avalos AM: Toll-like receptor-dependent immune complex activation of B cells and dendritic cells. Methods Mol Biol 1390: 249-272, 2016

34. Morimoto S, Nakano S, Watanabe T, Tamayama Y, Mitsuo A, Nakiri Y, Suzuki J, Nozawa K, Amano H, Tokano Y, et al: Expression of B-cell activating factor of the tumour necrosis factor family (BAFF) in T cells in active systemic lupus erythematosus: The role of BAFF inT cell-dependent B cell pathogenic autoantibody production. Rheumatology 46: 1083-1086, 2007.

35. Hua Z and Hou B: TLR signaling in B-cell development and activation. Cell Mol Immunol 10: 103-106, 2013.

36. Lee YH, Choi SJ, Ji JD and Song GG: Association between toll-like receptor polymorphisms and systemic lupus erythematosus: A meta-analysis update. Lupus 25: 593-601, 2016.

37. Bao Y and Cao X: The immune potential and immunopathology of cytokine-producing B cell subsets: A comprehensive review. J Autoimmun 55: 10-23, 2014.

38. Abdallah E, Waked E and Abdelwahab MA: Evaluating the association of interleukin-10 gene promoter-592 A/C polymorphism with lupus nephritis susceptibility. Kidney Res Clin Pract 35: 29-34, 2016.

39. Timóteo RP, Micheli DC, Teodoro RB, Freire M, Bertoncello D, Murta EF and Tavares-Murta BM: Characterization of inflammatory markers associated with systemic lupus erythematosus patients undergoing treatment. Rev Bras Reumatol Engl Ed 56: 497-503, 2016 (In English, Portuguese).

40. Heinemann K, Wilde B, Hoerning A, Tebbe B, Kribben A, Witzke O and Dolff S: Decreased IL-10(+) regulatory B cells (Bregs) in lupus nephritis patients. Scand J Rheumatol 45: 312-316, 2016. 
41. Steiman AJ, Gladman DD, Ibañez D, Noamani B, LandoltMarticorena C, Urowitz MB and Wither JE: Lack of interferon and proinflammatory cyto/chemokines in serologically active clinically quiescent systemic lupus erythematosus. J Rheumatol 42: 2318-2326, 2015.

42. Xu Y, Zeumer L, Reeves WH and Morel L: Induced murine models of systemic lupus erythematosus. Methods Mol Biol 1134: 103-130, 2014

43. Davison LM and Jørgensen TN: Sialic acid-binding immunoglobulin-type lectin H-positive plasmacytoid dendritic cells drive spontaneous lupus-like disease development in B6.Nba2 mice. Arthritis Rheumatol 67: 1012-1022, 2015.

44. Jain S, Park G, Sproule TJ, Christianson GJ, Leeth CM, Wang H, Roopenian DC and Morse HC III: Interleukin 6 accelerates mortality by promoting the progression of the systemic lupus erythematosus-like disease of BXSB. Yaa Mice. PLoS One 11: e0153059, 2016.

45. Lee HY, Kim YI, Lee JW, Byun JY, Park MS and Yeo SG: Decreased expression of TLR-9 and cytokines in the presence of bacteria in patients with otitis media with effusion. Clin Exp Otorhinolaryngol 6: 195-200, 2013.
46. Capobianco MP, Cassiano GC, Furini AA, Storti-Melo LM, Pavarino EC, Galbiatti AL, Fraga VD, Conceição LM, Couto VS, Couto AA and Machado RL: No evidence for association of the CD40, CD40L and BLYS polymorphisms, B-cell co-stimulatory molecules, with Brazilian endemic Plasmodium vivax malaria. Trans R Soc Trop Med Hyg 107: 377-383, 2013.

47. Tan X, Fujiu K, Manabe I, Nishida J, Yamagishi R, Nagai R and Yanagi Y: Choroidal neovascularization is inhibited via an intraocular decrease of inflammatory cells in mice lacking complement component C3. Sci Rep 5: 15702, 2015.

48. Taylor SH, Ripley BS, Martin T, De-Wet LA, Woodward FI and Osborne CP: Physiological advantages of $\mathrm{C} 4$ grasses in the field: A comparative experiment demonstrating the importance of drought. Glob Chang Biol 20: 1992-2003, 2014. 